\title{
Geographic Information System-based association between the sewage network, geographical location of intermediate hosts, and autochthonous cases for the estimation of risk areas of schistosomiasis infection in Ourinhos, São Paulo, Brazil
}

\author{
Raquel Gardini Sanches Palasio ${ }^{[1],[2], ~ A l i n e ~ N a z a r e ́ ~ B o r t o l e t o ~}{ }^{[1],}$ \\ Roseli Tuan ${ }^{[2]}$ and Francisco Chiaravalloti-Neto ${ }^{[1]}$
}

\author{
[1]. Universidade de São Paulo, Faculdade de Saúde Pública, Departamento de Epidemiologia, \\ Laboratório de Análise Espacial em Saúde, São Paulo, SP, Brasil. \\ [2]. Superintendência de Controle de Endemias, Laboratório de Bioquímica e Biologia Molecular, Luz, SP, Brasil.
}

\begin{abstract}
Introduction: Ourinhos is a municipality located between the Pardo and Paranapanema rivers, and it has been characterized by the endemic transmission of schistosomiasis since 1952. We used geospatial analysis to identify areas prone to human schistosomiasis infections in Ourinhos. We studied the association between the sewage network, co-occurrence of Biomphalaria snails (identified as intermediate hosts [IHs] of Schistosoma mansoni), and autochthonous cases. Methods: Gi spatial statistics, Ripley's K12-function, and kernel density estimation were used to evaluate the association between schistosomiasis data reported during 2007-2016 and the occurrence of IHs during 2015-2017. These data were superimposed on the municipality sewage network data. Results: We used 20 points with reported $\mathrm{IH}$; they were colonized predominantly by Biomphalaria glabrata, followed by B. tenagophila and B. straminea. Based on Gi statistics, a significant cluster of autochthonous cases was superimposed on the Christoni and Água da Veada water bodies, with distances of approximately $300 \mathrm{~m}$ and $2200 \mathrm{~m}$ from the points where B. glabrata and B. straminea were present, respectively. Conclusions: The residence geographical location of autochthonous cases allied with the spatial analysis of IHs and the coverage of the sewage network provide important information for the detection of human-infection areas. Our results demonstrated that the tools used for direct surveillance, control, and elimination of schistosomiasis are appropriate.
\end{abstract}

Keywords: Schistosomiasis. Biomphalaria. Spatial analysis. Gi statistics. Georeferencing. Epidemiology.

\section{INTRODUCTION}

Schistosomiasis is a parasitic infection that is considered a neglected tropical disease ${ }^{1}$. Schistosomiasis mansoni infection in Brazil is associated with the development of the parasite Schistosoma mansoni Sambon, 1907 in three species of snails of the genus Biomphalaria (Preston, 1910), namely, B. glabrata (Say, 1818), B. tenagophila (Orbigny, 1835), and B. straminea (Dunker, 1848) ${ }^{2}$. Human infections are highly prevalent, mainly in the northeast of the country and in the southeast, where it is endemic in some areas ${ }^{3}$.

\footnotetext{
Corresponding author: Raquel Gardini Sanches Palasio.

e-mail: raquelpalasio@alumni.usp.br

(iD) https://orcid.org/0000-0003-1564-0871

Received 7 December 2020

Accepted 26 February 2021
}

In the state of São Paulo, human infections occur in specific areas where schistosomiasis endemicity is low ${ }^{3}$. Among these areas, the Middle Paranapanema region, where it borders with the state of Paraná, is usually reported as an important endemic region ${ }^{4}$. However, a recent study using spatial analysis tools in an area considered a GeoSentinel surveillance site for schistosomiasis pointed out that human schistosomiasis infections are more likely to occur in Ourinhos than in the other regions across the 25 municipalities of the Hydrographic Unit Water of Resources Management of Middle Paranapanema (UGRHI-17) ${ }^{5,6,7}$. Currently, Ourinhos accounts for $93 \%$ of all autochthonous cases in Middle Paranapanema ${ }^{5}$, with cases reported since $1952^{8,9}$.

The schistosomiasis cases observed in Ourinhos are probably associated with B. glabrata, which is a natural host to $S$. mansoni in the municipality ${ }^{10,11}$. This species was initially identified in Ourinhos in $1919^{12}$ and continues to proliferate in water bodies in 
this municipality ${ }^{13,14}$. B. tenagophila and B. straminea, two other S. mansoni intermediate-host (IH) species, have also been described/ observed in the area ${ }^{13,14}$.

The spatial association between the occurrence of autochthonous cases and the presence of IHs can be analyzed using Gi spatial statistics. This tool, with the support of geographic information systems (GIS), uses the geographic coordinates of locations to find spatial clusters of a certain measure or quantity around a specific point and infer the distances at which these clusters are statistically significant ${ }^{15}$. Previous studies have used this tool (Gi or Gi* statistics) to analyze schistosomiasis in Africa ${ }^{16,17,18,19}$ and vector-borne diseases, such as dengue, in Brazil ${ }^{20}$. Additionally, other studies have

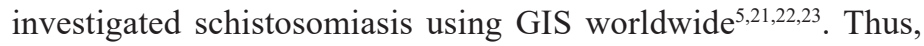
GIS and spatial analysis tools may contribute to identifying areas with the highest risk of human schistosomiasis infection and other diseases and consequently help guide public health measures ${ }^{21,24}$.

The present study used a GIS-based approach to identify rural and urban areas at risk of schistosomiasis transmission in Ourinhos
(São Paulo, Brazil), combining data sources related to the presence of snails that act as $S$. mansoni IHs, the historical occurrence of human infection, and the sewage network.

\section{METHODS}

\section{Study area}

The study was conducted in the municipality of Ourinhos, southwest of the state of São Paulo (22 $5844^{\prime \prime} \mathrm{S}, 49^{\circ} 5215^{\prime \prime} \mathrm{W}$, Figure 1). The municipality extends over an area of $296 \mathrm{~km}^{2}$ and had an estimated population of 113,542 inhabitants in 201925,26, $97 \%$ of which lived in urban areas ${ }^{25}$. The municipality is covered by a variety of freshwater bodies located between the Pardo and Paranapanema rivers, which are tributaries of the Paraná river ${ }^{27}$.

\section{Data source}

The geographic coordinates related to each taxonomic group identified from 20 collection points in eight of the freshwater bodies positive for IH Biomphalaria species and the frequency

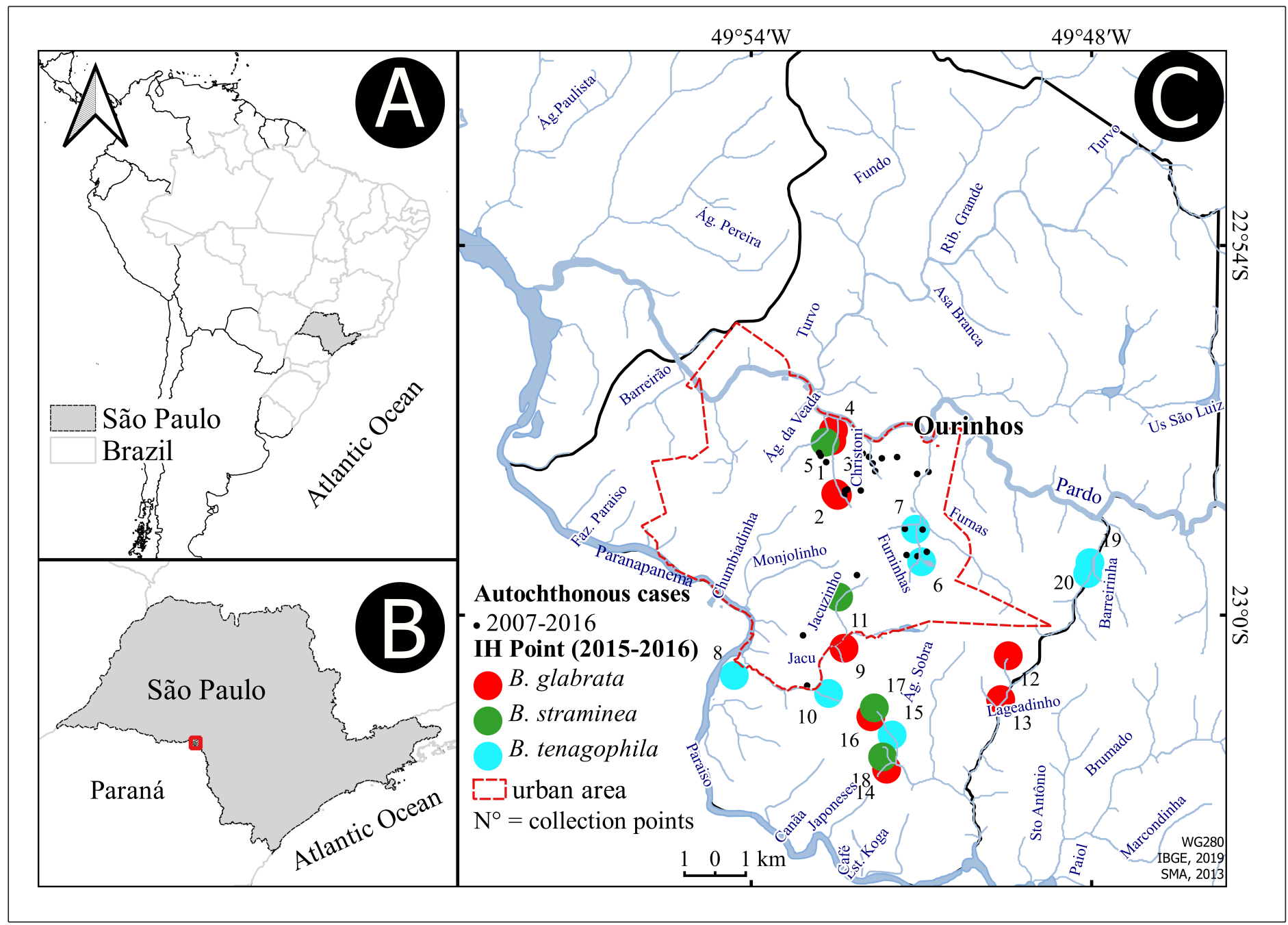

FIGURE 1: Maps of (A) Brazil, South America; (B) the state of São Paulo; and (C) the municipality of Ourinhos, showing the distribution of S. mansoni intermediatehost $(\mathrm{IH})$ species (Biomphalaria) identified during 2015-2017, the autochthonous cases of 2007-2016, and the water bodies in Ourinhos. The numbers ( $\mathrm{N}^{\circ}$ ) in Figure 1C correspond to the collection points presented in Table 1. Source: IBGE ${ }^{36,37}$; SMA ${ }^{38}$; SUCEN/Palasio et al. ${ }^{14}$; SINAN/CVE. 
of specimens per species are displayed in Table 1. These data integrate a survey conducted in 2015-2017 at 141 sampling points located along 26 water bodies in urban, peri-urban, and rural areas in the geographical limits of the Ourinhos municipality, according to malacological and geospatial approaches described by Palasio et al. ${ }^{14}$. Of the 141 points sampled, 121 were negative for the presence of IHs or were colonized by species of Biomphalaria that were naturally refractory to $S$. mansoni ${ }^{14}$. As reported in our preliminary and pivotal study ${ }^{14}$, the snails sampled were examined in the laboratory to analyze the presence of cercariae from trematodes ${ }^{28}$, and the species were concurrently identified through morphological characters according to Paraense $(1975,1981)^{29,30}$ and the DNA barcode protocol ${ }^{31,32,33}$. A detailed explanation of the parasitological approach and the morphological and molecular identification of snails used in this study has been provided by Palasio et al. ${ }^{14}$.

Information regarding schistosomiasis cases from 2007 to 2016, including notification date, residence geographical location, probable infection site (PIS), and epidemiologic classification, was obtained from the National Notifiable Disease Information System (SINAN). Access to the necessary information was provided by the Alexandre Vranjac Center for Epidemiologic Surveillance (CVE). We used this information to obtain the frequencies of the occurrence of autochthonous, imported, and unknown-origin cases in the municipality.

Once the residence geographical location for each autochthonous schistosomiasis case was known, the batch geocoding tool ${ }^{34}$, which uses Google Earth, was used to obtain the respective geographic coordinates (datum WGS84). Cartographic material (maps with rivers, census tract layers, and sanitation data) was obtained from the Brazilian Institute of Geography and Statistics (IBGE) $25,35,36,37$, the Secretariat for the Environment of the State of São Paulo (SMA) ${ }^{38}$, and the National Secretariat for Environmental Sanitation (SNSA) in partnership with the Brazilian National Water Agency (ANA) ${ }^{39}$. The points corresponding to the geographic coordinates of snail IHs and autochthonous schistosomiasis cases were imported into and viewed using QGIS software version 3.10.5 $5^{40}$.

A fundamental part of the current study was the data related to the percentages of residents served by the sewage system, septic tanks, and/ or rudimentary tanks ${ }^{25}$, according to census tracts $^{35}$. These data were computed using the

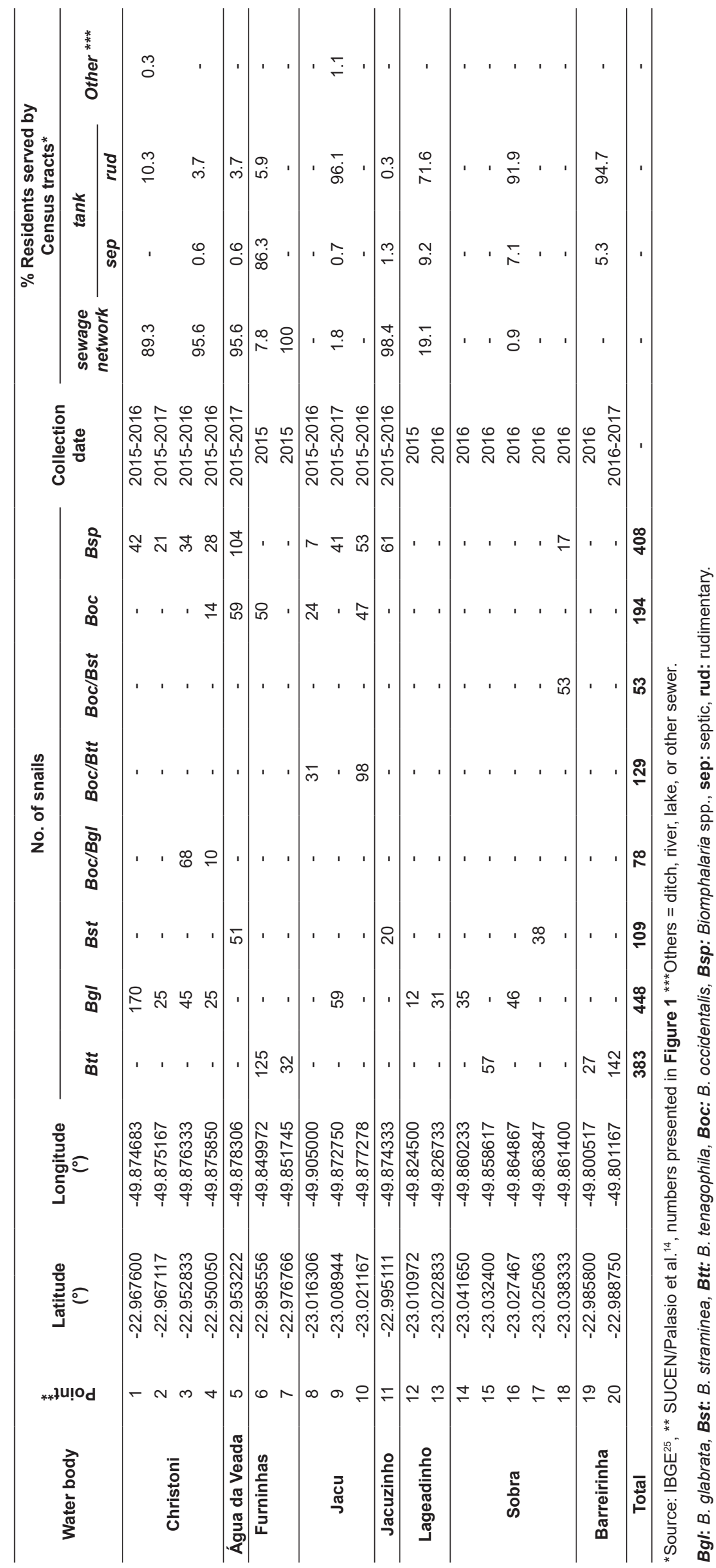


MMQGIS plugin ${ }^{41}$ coupled with spatial join geographic operation, both available on QGIS version 3.10.5 $5^{40}$. To do this, we considered the map of the census tracts, statistical data from the 2010 census $^{25,35}$, and geographical coordinates of IHs.

\section{Data analysis}

The relationship between the spatial distribution of autochthonous cases of schistosomiasis from 2007 to 2016 and the presence of IHs from 2015 to 2017 was analyzed using Gi spatial statistics, which is an indicator of local spatial association ${ }^{15,42}$. These statistics considered the occurrence of autochthonous cases around the points where IH snails were found.

The schistosomiasis incidence rates by census tracts were calculated using the MMQGIS plugin ${ }^{41}$ in QGIS $^{40}$. In the 2010 population ${ }^{25}$, the centroid coordinates of the census tracts ${ }^{35}$ and the coordinates of georeferenced schistosomiasis cases were considered. Gi statistics were calculated for each geographic coordinate where IHs were detected, taking into account the incidence rates. This allowed us to obtain a profile of schistosomiasis based on the spatial pattern of autochthonous schistosomiasis cases and its relationship with freshwater bodies and the IH snails that colonize them. A significance level of 5\% was used, which corresponded to the minimum value of the Gi statistics (3.2889) $(\mathrm{N}=100)$ according to Table 3 of the paper published by Ord and Getis ${ }^{15}$.

The application of the Gi statistics took into account the measured attribute values in the pairs of coordinates corresponding to the locations analyzed (schistosomiasis incidence rates in census tract centroids). As it is a focal statistic, it considered the pair of geographic coordinates of each focus with IH (i) without taking into account the value of the attribute at this point ${ }^{15}$.

Gi can be written as $\Sigma_{\mathrm{j}} \mathrm{W}_{\mathrm{ij}}(\mathrm{d}) \mathrm{x}_{\mathrm{j}} / \Sigma_{\mathrm{j}} \mathrm{x}_{\mathrm{j}}$, for $\mathrm{i} \neq \mathrm{j}$, where $j$ represents the geographic coordinates of the centroid of the census tracts where there are schistosomiasis cases, $\mathrm{W}_{\mathrm{ij}}$ the binary and symmetric matrix that defines the neighborhood between the areas, $x_{j}$ the values of the incidence rates of the cases in the position of each $j$, and $d$ the measure of the distance established by the neighborhood model. This calculation was performed with the sum of neighboring samples in relation to the position of $i$, wherein the value $x i$ was not included in the sum as the place where IHs were collected, and the incidence rate was considered null $(=0)^{15}$.

In the present study, a significant result for these statistics would indicate that the location in question may be considered a potential infection area for schistosomiasis. Gi statistics were calculated using the 'spdep' package ${ }^{43}$ in $\mathrm{R}$ version 3.2.2 $2^{44}$. The presence of clusters was investigated using a maximum distance of $4000 \mathrm{~m}$ between each point where IHs were present and the centroids of the census tracts.

Furthermore, the spatial dependence between the distribution of points corresponding to autochthonous cases of schistosomiasis and those corresponding to places where the IHs were found was evaluated by considering the geographic coordinates of the autochthonous cases and the IH, using Ripley's K12-function ${ }^{45,46}$ and the R software version 3.2.2 $2^{44}$ with the 'Splancs' package ${ }^{47}$. We used the borders of the study area in a shapefile format and considered the coordinates of the cases and IHs in the UTM format. The result of the K12-function allowed us to verify the radius of influence, which is the limited and statistically significant distance where a positive spatial dependence between the two distributions of points occurs. We used the geographic coordinates of the autochthonous cases of schistosomiasis and the radius of influence data of the K12-function result to estimate the kernel density with a plugin available in the program QGIS version 3.10.5 .

With the coordinates of the points where IHs were found and the radius of influence of each point analyzed in the Gi statistics (distances considered significant, higher limit), it was possible to identify the clusters of autochthonous cases around points with IHs. We performed this procedure using the MMQGIS plugin ${ }^{41}$ and created a buffer geographic operation available on QGIS $^{40}$. We merged all clusters into one cluster, which was restricted to the Ourinhos urban area. This cluster map obtained using Gi statistics was superimposed onto the respective autochthonous case hotspots obtained using the kernel tool.

\section{Ethical considerations}

The project was approved by the Faculdade de Saúde Pública of Universidade de São Paulo, Committee for Ethics in Research, the Plataforma Brasil system, Ministério da Saúde - Conselho Nacional de Saúde (number, CAAE: 53559816.0.0000.5421).

\section{RESULTS}

\section{IH occurrence in Ourinhos}

The geographical occurrence points for B. glabrata, B. tenagophila, and $B$. straminea over the 20 locations sampled across eight freshwater bodies assigned as breeding sites for IHs demonstrated the predominant occurrence of B. glabrata (Figure 1C). We also found that the relative abundance of B. glabrata was higher in Christoni, Sobra, and Jacu than that of the other two IHs investigated (Table 1, Figure 2). However, none of the snails were infected with S. mansoni in the parasitological analysis, as reported by Palasio et al. ${ }^{14}$. Overall, the three natural S. mansoni-IH species occurred in the urban, peri-urban, and rural areas of Ourinhos (Figure 1C, Figure 2).

\section{Frequency of schistosomiasis and PIS and their relationship with the IH and sewage system}

The frequencies of autochthonous, imported, and unknownorigin cases were $39.7 \%$ (25), 7.9\% (5), and 52.4\% (33), respectively. On average, 6.3 cases per year were detected. Using information from the PIS in the epidemiological survey records, eight PIS were geocoded in the water bodies of Christoni, Furninhas, Jacu, Sobra (Pinhos Lake), Lageadinho, Chumbiadinha (Lake), Furnas (Fapi Lake), and Lake of São Luiz plant (Figure 3). It is noteworthy that the presence of IHs was only found in the first five locations, the majority of PIS were vague, and information was not available for $48 \%$ of them, making geocoding impossible.

In the water bodies of Chumbiadinha, Lake of São Luiz plant, and Furnas, B. glabrata were reported until 2009, 2009, and 2012, respectively ${ }^{13,48,49}$. Currently, only B. occidentalis Paraense, 1981 has been identified in these sites ${ }^{14}$, and this species is not susceptible 


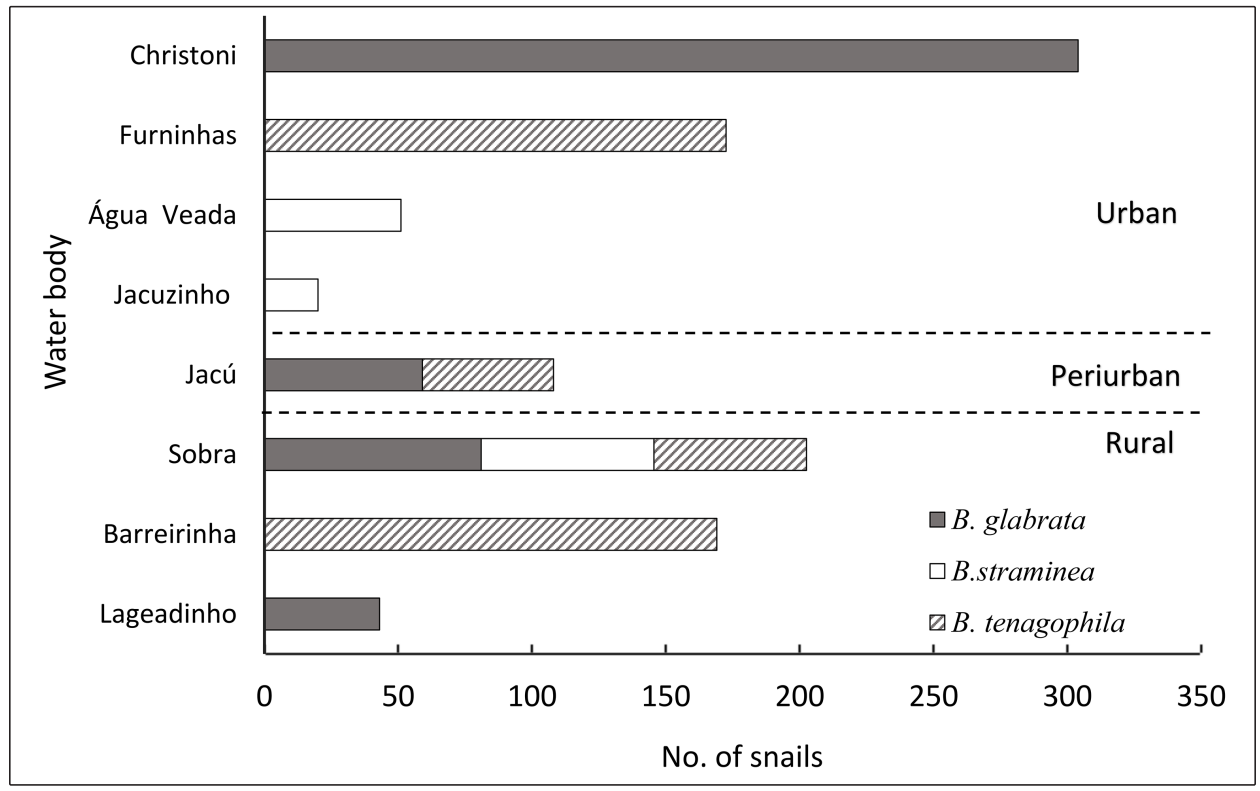

FIGURE 2: Number of intermediate-host specimens (Biomphalaria species) of S. mansoni collected during 2015-2017 in eight water bodies in the urban, peri-urban, and rural areas of the municipality of Ourinhos, SP, Brazil.

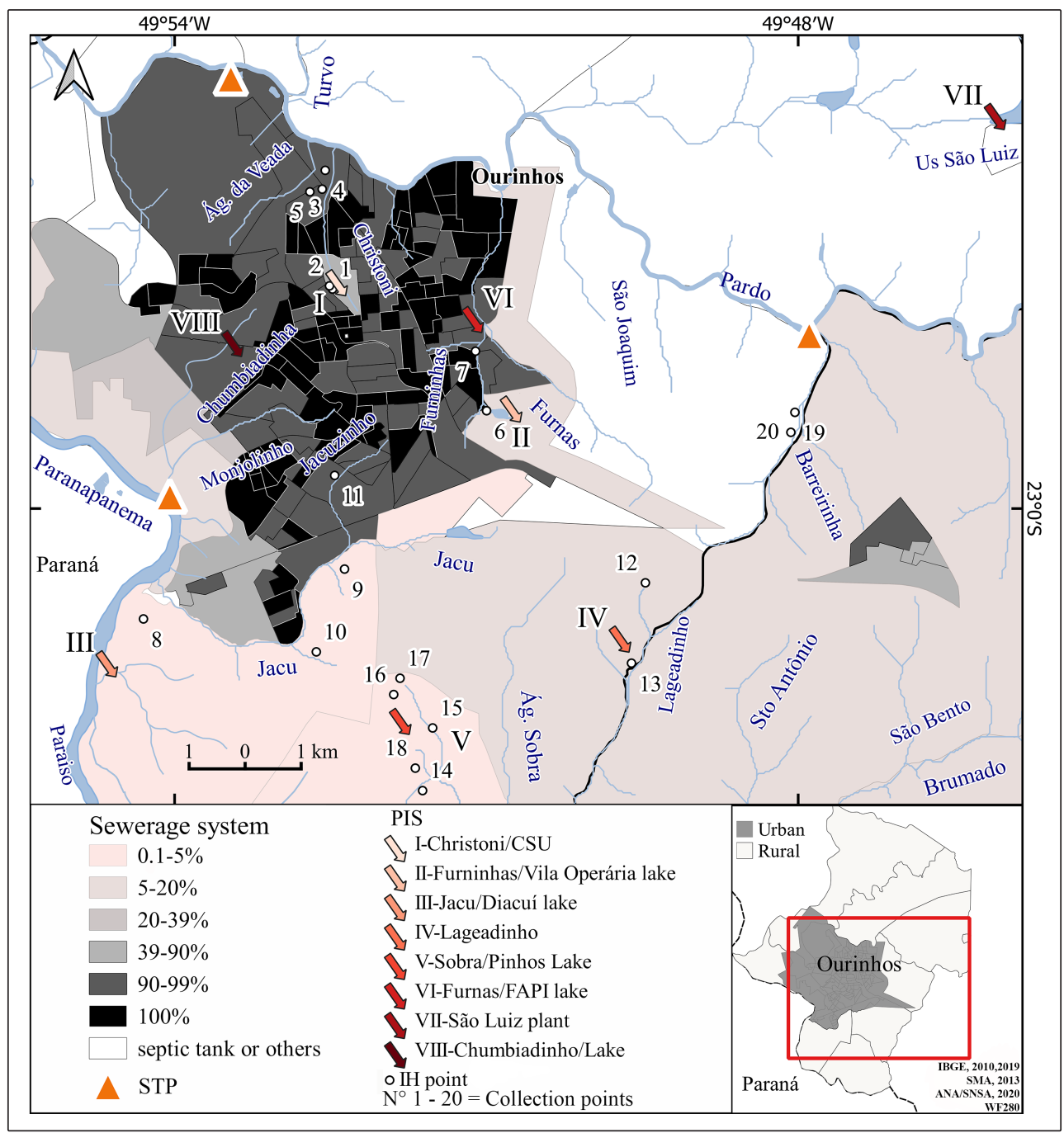

FIGURE 3: Map of the municipality of Ourinhos, state of São Paulo, Brazil, highlighting the main probable infection site (PIS), percentage of residents served by a sewage network according to the census tracts, sewage treatment plants (STPs), and points where S. mansoni intermediate hosts $(\mathrm{IHs})$ were found. The numbers $\left(\mathrm{N}^{\circ}\right)$ in this figure correspond to the collection points presented in Table 1. Source: IBGE ${ }^{25,35,36,37}$; SMA $^{38}$; ANA/SNSA ${ }^{39}$. 
to $S$. mansoni ${ }^{50}$. IHs were found in overlapping areas with a high percentage of residents served by the sewage network as well as in places served by tanks or other systems (Figure 3, Table 1).

\section{Association between IH occurrence and autochthonous cases}

Figure 4A shows the results of the Gi statistics with locations considered potential risk areas for human schistosomiasis infection as well as the extent of the concatenated clusters of autochthonous cases around these points and the kernel density map.
Significant clusters of autochthonous cases were superimposed on the Christoni stream region from approximately $300 \mathrm{~m}$ (lower limit) to $2200 \mathrm{~m}$ (higher limit) from sites where B. glabrata was detected. Another cluster was superimposed on the Água da Veada stream region at a distance of approximately 1600-2000 m (Figure 4A-B) from the $B$. straminea collection site $^{14}$ (Table 1). All clusters were combined into a single cluster (Cluster 1 in Figure 4A).

The graph obtained using the K12-function shown in Figure 4C indicates a positive spatial dependence up to a distance of approximately $759 \mathrm{~m}$ between autochthonous cases and IH snails.

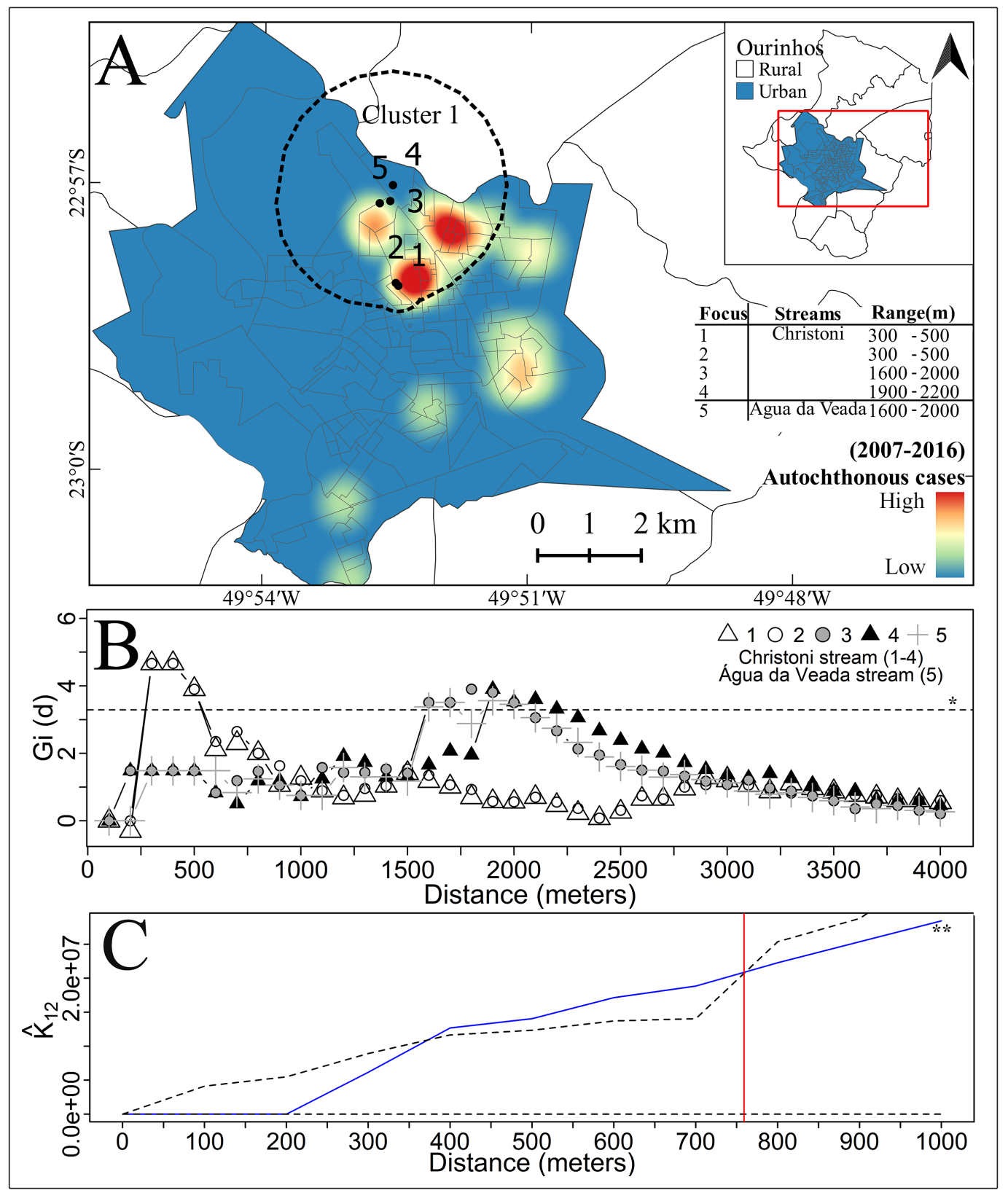

FIGURE 4: (A) Kernel density map of the urban area (759 m radius of influence) showing the distribution of autochthonous schistosomiasis cases and significant clusters in the Gi statistics of cases around sampling points with intermediate hosts (foci). (B) Graph showing significant clusters of autochthonous cases around the Christoni stream and Água da Veada stream sampling points with $\mathrm{IH}$. (C) Graph of the bivariate K12-function analysis in Ourinhos, SP, Brazil, during the 2007-2016 period. (B)* Statistically significant values are above the horizontal line $(\mathrm{G} i[\mathrm{~d}]>3.28, P<0.05)$; (C) ${ }^{\star *}$ The blue curve above the envelope shows a positive spatial dependence between the autochthonous cases of schistosomiasis and the $\mathrm{IH}$ up to a distance of $\sim 759 \mathrm{~m}$. 


\section{DISCUSSION}

In this study, the association of data from autochthonous cases reported in Ourinhos (2007-2016) with the spatial location of IHs and the sewage network allowed the identification of the Christoni freshwater body as the most suitable area for human schistosomiasis infection. The results obtained through statistics corroborated previous results ${ }^{5,51}$ which showed that the Christoni stream was the area most probably at highest risk of peridomestic schistosomiasis transmission $^{51,52}$. Interestingly, in addition to the identification of specific points, the results obtained using Gi statistics provided important information regarding the significant distances that should relate to the local occurrence of schistosomiasis infection, a phenomenon that has not been previously reported in the literature.

The inventory of species in the Christoni stream shows that B. glabrata is abundant and predominates at four specific points ${ }^{14}$, which corroborates data from previous surveys ${ }^{10,13,48,49}$. Although the B. glabrata samples collected were reported to be negative for cercariae infection, this species is known to be the most suitable IH for the development and transmission of the parasite ${ }^{11,53}$. Based on previous studies, it is considered the most competent $\mathrm{IH}$ species for S. mansoni transmission in the Paranapanema region ${ }^{51,54}$.

In Ourinhos, B. glabrata predominance in census tracts, where sanitary sewage is still performed using a septic and/or rudimentary tank, is relevant and of concern from a medical perspective. In the case of the census tracts where the Christoni stream is located, $89.3 \%$ of the residents are served by a sewage network and $10.6 \%$ by a rudimentary tank and other drains ${ }^{25}$. This percentage pattern of sanitary sewage is a potential explanation for the decrease in the number of autochthonous cases in recent years as well as for the maintenance of focal transmission in this municipality ${ }^{5}$.

B. straminea is resilient to extreme environmental variations and is capable of adapting to altered environments ${ }^{55}$. The presence of the B. straminea $\mathrm{IH}$ in the Água da Veada stream, where previous surveys indicated colonization by $B$. tenagophila ${ }^{13}$ and B. glabrata $^{49,56}$, is further evidence of the expansion potential of $B$. straminea. Regarding the natural susceptibility of $B$. straminea to $S$. mansoni, the physiological adaptation of this species to the parasite is relatively high in snails inhabiting regions of northeastern Brazil $^{57}$. The occurrence of B. straminea in Água da Veada and the fact that a portion of the residents living nearby are still served by septic $(0.6 \%)$ or rudimentary $(3.7 \%)$ tanks ${ }^{25}$ suggest the need for enhanced surveillance of areas colonized by this species. Although designated as a statistically significant cluster for schistosomiasis infection, in Água da Veada are more likely to result from a bias associated with its closeness to Christoni.

Although the Gi statistics considered only Christoni to have significant associations, the water bodies of Sobra, Lageadinho, and Jacu require monitoring, as $B$. glabrata ${ }^{14}$ is also present therein. In addition, the percentage of residents served by the sewage system near these areas was below $20 \%{ }^{25}$. B. glabrata presence has been registered in the water bodies of Jacu, located in peri-urban areas, in the past and continues today ${ }^{13,14,58}$. In the Sobra and Lageadinho water bodies, located in rural areas, the first record of this species was in $2009^{49}$. Until then, only B. straminea had been recorded in Sobra water bodies ${ }^{59}$.
The results of this study demonstrate that the use of GIS tools in association with malacology, epidemiological data, and sewerage infrastructure has the potential to improve schistosomiasis control, fostering the use of new technologies to locally eliminate future infections.

One of the limitations of this study is the discrepancy between the periods of collection of snails (2015-2017) and of data on schistosomiasis cases (2007-2016). Despite this incoherence, such a limitation may be overcome by comparing our results with those from the literature ${ }^{13,48,49,54,56,58,59}$.

In the 2007-2016 period, the Gi statistics made it possible to exclusively identify the Christoni stream as a location characterized by significant clusters of autochthonous cases associated with the presence of B. glabrata. Therefore, this species is a candidate for the main target of environmental monitoring measures in this municipality. In addition, the use of this technique allowed us to verify that the association between the residence geographical location of autochthonous cases and the spatial distribution of $\mathrm{IH}$ provides vital information regarding potential transmission areas. Despite the absence of cercariae in the samples of $B$. glabrata collected in Ourinhos, the high susceptibility of this species to $S$. mansoni in laboratory conditions ${ }^{11,60}$ indicates the risk of schistosomiasis persistence in this region.

Moreover, the Gi statistics partially overcame the limitation related to the lack of precise information regarding the location of the PIS, which is consistent with the information that characterizes the transmission of schistosomiasis as being predominantly peridomestic $^{51}$. The proximity between water bodies and residences is another typical characteristic of the incipient urbanization process.

The fact that the significant distance in the Gi statistics is approximately $2 \mathrm{~km}$ allowed us to calibrate the surveillance activities to a concise and statistically pre-established area. Accordingly, it is possible to develop schistosomiasis control and monitoring activities at well-defined focal points, rationalizing the use of public resources, since Brazil spent approximately 7.7 million dollars in 2015 to control the infection ${ }^{61}$. Therefore, the information presented in this study as well as the tools used may be adequate to develop and direct surveillance actions that contribute to the control and even elimination of schistosomiasis in the municipality of Ourinhos.

\section{ORCID}

Raquel Gardini Sanches Palasio: 0000-0003-1564-0871

Aline Nazaré Bortoleto: 0000-0002-9661-7341

Roseli Tuan: 0000-0001-7379-783X

Francisco Chiaravalloti-Neto: 0000-0003-2686-8740

\section{ACKNOWLEDGMENTS}

The authors would like to thank the Superintendência de Controle de Endemias (SUCEN) for providing fieldwork, laboratorial activities and snails of Ourinhos, and Alexandre Vranjak Center for Epidemiological Surveillance (CVE) for providing data on schistosomiasis cases. 


\section{FINANCIAL SUPPORT}

CAPES for providing doctoral fellowship for RGSP. CNPq for providing an undergraduate for ANB and research productivity fellowship for FCN (PQ-2, 307739/2016-3). SUCEN, Head Office (Grant $\left.\mathrm{n}^{\circ} 1819 / 2016\right)$ for providing financial support for fieldwork and laboratorial activities for RT.

\section{AUTHORS' CONTRIBUTION}

RGSP: data collection and analysis, bibliographical survey, address geocoding, spatial analysis, elaboration of thematic maps, discussion of the results, writing-review and conference of the paper; ANB: data collection and analysis, address geocoding, spatial analysis, elaboration of thematic maps, discussion of the results, writing-review and conference of the paper; RT: supervision, implementation and management of the research project; taxonomy and systematics of Biomphalaria genus; discussion of the results; writing-review and conference of the paper; FCH: supervision, implementation and development of the research project, management of spatial analysis; elaboration of thematic maps; discussion of the results; writingreview and conference of the paper.

\section{CONFLICT OF INTEREST}

The authors declare that there is no conflict of interest.

\section{REFERENCES}

1. World Health Organization (WHO). Integrating neglected tropical diseases into global health and development: fourth WHO report on neglected tropical diseases. 2017 [updated 2019; cited 2020]. Available from: https://www.who.int/neglected_diseases/resources/en/

2. Teodoro TM, Janotti-Passos LK, Carvalho OS, Caldeira RL. Occurrence of Biomphalaria cousini (Mollusca: Gastropoda) in Brazil and its susceptibility to Schistosoma mansoni (Platyhelminths: Trematoda). Mol Phylogenet Evol. 2010;57(1):144-51.

3. Ministério da Saude (MS). Secretaria de Vigilância em Saúde. Vigilância da Esquistossomose Mansoni: diretrizes técnicas. $4^{a}$ edição. Brasília: MS; 2014. 13-20 p

4. Centro de Vigilância Epidemiológica (CVE). Vigilância Epidemiológica. Divisão de Doenças de Transmissão Hídrica e Alimentar. Normas e Instruções [Documento técnico]. São Paulo: CVE; 2007. 45 p.

5. Palasio RGS, Bortoleto AN, Rosa-Xavier IG, Andrighetti MTM, Tuan R, Chiaravalloti-Neto F. Schistosomisasis in Middle Paranapanema river region, state of São Paulo, Brazil: Does it matter today for public health? Rev Soc Bras Med Trop. 2019;52:e20180447.

6. Eduardo MBP. Avaliação da Esquistossomose no Estado de São Paulo. Documento técnico/Relatório de Avaliação. Secretaria do Estado da Saúde, Coordenadoria de Controle de Doenças, Centro de Vigilância Epidemiológica, Divisão de Doenças de Transmissão Hídrica e Alimenta, 2008, 59 p.

7. Comitê da Bacia Hidrográfica do Médio Paranapanema (CBH-MP). Relatório de Situação dos Recursos Hídricos 2018 (Ano Base: 2017) - UGRHI-17. CBH-MP. 2018. [updated 2019]. Available from: http:// cbhmp.org/publicacoes/relatorios/

8. Ferreira JM, Meira JA. Três casos de esquistossomose mansoni procedentes do interior do estado de São Paulo (Ourinhos, Palmital e Ipauçu). Foco autóctone na cidade de Ourinhos. Rev Paul Med. 1952;41(1):15-8.
9. Sistema de Informação de Agravos de Notificação (SINAN). Ministério da Saúde. Casos confirmados por Evolução e por Autóctone Mun. Res. segundo Município de residência. Brasília: SINAN; 2019 [updated 2020; cited 2020]. Available from: http://portalsinan.saude.gov.br/sinan-net/

10. Rey L. Primeiro encontro de planorbídeos naturalmente infestados por furcocercárias de $S$. mansoni no planalto paulista (Ourinhos). Rev Clin S Paulo. 1952;28(5-6):57-64.

11. Magalhães LA, Dias LCS. Estudo da suscetibilidade da Biomphalaria glabrata de Ourinhos (SP), à infecção pelo Schistosoma mansoni de Belo Horizonte (MG), e de São José dos Campos (SP). Rev Saude Publica. 1973;7(3):295-7.

12. Paraense WL. Distribuição dos caramujos no Brasil. An Acad Mineira Med. 1986;14:117-28.

13. Tuan R. Diversity and distribution of the Biomphalaria species in the middle reaches of the Paranapanema River, São Paulo, SP, Brazil. Biota Neotrop. 2009;9(1):279-83.

14. Palasio RGS, Rosa-Xavier IG, Chiaravalloti-Neto F, Tuan R. Biodiversity of Biomphalaria spp. freshwater snails and associated limnic mollusks in areas with schistosomiasis risk, using molecular and spatial analysis tools. Biota Neotrop. 2019;19(4):e20190746.

15. Ord JK, Getis A. Local spatial autocorrelation statistics: distributional issues and an application. Geogr Anal. 1995;27:286-306.

16. Clennon JA, Mungai PL, Muchiri EM, King CH, Kitron U. Spatial and temporal variations in local transmission of Schistosoma haematobiumin Msambweni, Kenya. Am J Trop Med Hyg. 2006;75(6):1034-41.

17. Mutuku FM, King $\mathrm{CH}$, Bustinduy AL, Mungai PL, Muchiri EM, Kitron U. Impact of drought on the spatial pattern of transmission of Schistosoma haematobium in coastal Kenya. Am J Trop Med Hyg. 2011;85(6):1065-70.

18. Manyangadze T, Chimbari MJ, Gebreslasie M, Mukaratirwa S Risk factors and micro-geographical heterogeneity of Schistosoma haematobium in Ndumo area, uMkhanyakude district, KwaZulu-Natal, South Africa. Acta Trop. 2016;159:176-84.

19. Nyandwi E, Veldkamp A, Amer S, Karema C, Umulisa I. Schistosomiasis mansoni incidence data in Rwanda can improve prevalence assessments, by providing high-resolution hotspot and risk factors identification. BMC Public Health. 2017;17(1):845.

20. Barbosa GL, Lage MDO, Andrade VR, Gomes AHA, Quintanilha JA, Chiaravalloti-Neto F. Influência de pontos estratégicos na dispersão de Aedes aegypti em áreas infestadas. Rev Saude Publica. 2019;53:29.

21. López MS, Müller GV, Sione WF. Analysis of the spatial distribution of scientific publications regarding vector-borne diseases related to climate variability in South America. Spat Spatiotemporal Epidemiol. 2018;26:35-93.

22. Clark NJ, Umulisa I, Ruberanziza E, Owada K, Colley DG, Ortu G, et al. Mapping Schistosoma mansoni endemicity in Rwanda: a critical assessment of geographical disparities arising from circulating cathodic antigen versus Kato-Katz diagnostics. PLoS Negl Trop Dis. 2019;13(9):e0007723.

23. Chen Y, Liu J, Xiao Y, Zhong C, Wei F, Liu S. Spatiotemporal pattern analysis of schistosomiasis based on village level in the transmission control stage in lake and marshland areas in China. Parasitol. 2020;147:199-212.

24. Chiaravalloti-Neto F. O geoprocessamento e saúde pública. Arq Cienc Saude. 2017;23(4):01-02.

25. Instituto Brasileiro de Geografia e Estatística (IBGE). Censo demográfico 2010. Resultados do Universo. Agregados por Setores censitários. SP exceto a capital (Atualizações 2019). IBGE; 2010 [updated 2019; cited 2020]. Available from: http://www.ibge.gov.br/estatistica/downloads-estatisticas 
26. Instituto Brasileiro de Geografia e Estatística (IBGE). Estimativas de população residente nos Municípios Brasileiros com data de referência em $1^{\circ}$ de julho de 2019. IBGE; 2019 [updated 2019; cited 2020]. Available from: https://www.ibge.gov.br/estatisticas-novoportal/sociais/ populacao/9103-estimativas-de-populacao.html $?=\& \mathrm{t}=$ resultados

27. Peron AF, Piroli EL. Projeto Apps: Conhecendo e cuidando da bacia hidrográfica do Rio Pardo, Centro de Estudo e Divulgação de Informações sobre Áreas Protegidas, Bacias Hidrográficas e Geoprocessamento. $1^{\text {a }}$ edição. UNESP: Ourinhos/SP: CEDIAP-GEO;2011. 23 p.

28. Ministério da Saude (MS). Secretaria de Vigilância em Saúde. Departamento de Vigilância Epidemiológica. Vigilância e controle de moluscos de importância epidemiológica: diretrizes técnicas: Programa de Vigilância e Controle da Esquistossomose (PCE). $2^{\mathrm{a}}$ edição. Brasília: MS; 2008. $177 \mathrm{p}$.

29. Paraense WL. Estado atual da sistemática dos planorbídeos brasileiros. Arq Mus Nac. 1975;55:105-28.

30. Paraense WL. B. occidentalis sp.n. from South America. Mem Inst Oswaldo Cruz. 1981;76(2):199-211.

31. Folmer O, Black M, Hoeh W, Lutz R, Vrijenhoek R. DNA primers for amplification of mitochondrial cytochrome $\mathrm{C}$ oxidase subunit I from diverse metazoan invertebrates. Mol Mar Biol Biotechnol. 1994;3(5):294-99.

32. Herbert PD, Cywinska A, Ball SL, Dewaard JR. Biological identifications through DNA barcodes. Proceedings. J Biol Med Sci. 2003;270(1512):313-21.

33. Tuan R, Ohweiller F, Palasio RGS, Zanna R, Guimaráes MCA. Chapter 15: Pattern of genetic divergence of mitochondrial DNA sequences in Biomphalaria tenagophila complex species under barcoding perspective. In: Rokni MR editors. Schistosomiasis. Tehran, Iran, Intech; 2012. p 293-309.

34. Zwiefelhofer DB. Batch Geocoding. Find Latitude and Longitude, 2008 [updated 2017; cited 2019]. Available from: http://www. findlatitudeandlongitude.com/batch-geocode/

35. Instituto Brasileiro de Geografia e Estatística (IBGE). Setor Censitário 2010. Mapas, bases e referenciais, bases cartográficas, malhas digitais. IBGE; 2010 [updated 2019; cited 2020]. Available from: http://mapas.ibge.gov.br

36. Instituto Brasileiro de Geografia e Estatística (IBGE). Base Contínua 250 mil, Massa d'água, Hidrografia. Geociência. Cartas e Mapas. IBGE; 2019 [updated 2020; cited 2020]. Available from: http://mapas. ibge.gov.br/geociencias/cartas-e-mapas/bases-cartograficas-continuas/

37. Instituto Brasileiro de Geografia e Estatística (IBGE). Malha Municipal 2019 (escala 1:250.000). Mapas, bases e referenciais, bases cartográficas, malhas digitais. IBGE; 2019 [updated 2020; cited 2020]. Available from: https://mapas.ibge.gov.br/bases-e-referenciais/bases-cartograficas/ malhas-digitais.html

38. Secretaria de Meio Ambiente do estado de São Paulo (SMA). Rede de drenagem do Estado de São Paulo obtida a partir da base do gisat (cartas topográficas na escala 1:50.000) por processo automático - coordenadoria de planejamento ambiental. São Paulo: SMA; 2013 [updated 2019; cited 2020]. Available from: http://www.ambiente.sp.gov.br/cpla/mapa-darede-de-drenagem-do-estado-de-sao-paulo/

39. Agência Nacional de Águas (ANA). Secretaria Nacional de Saneamento Ambiental. Atlas esgotos: despoluição de bacias hidrográficas. Estação de Tratamento de Esgoto - 2019 (shp). Brasil. Brasília: ANA; 2020. [updated 2020; cited 2020]. Available from: http://metadados.ana.gov. br/geonetwork/srv/pt/main.home/

40. QGIS Development Team. QGIS Version 3.10.5. Geographic Information System. Open Source Geospatial Foundation Project; 2020 [updated 2020; cited 2020]. Available from: http://www.qgis.org/
41. Minn M. Mmqgis. A collection of QGIS vector layer operation plugins. 2018 [updated 2020; cited 2020]. Available from: http://michaelminn. com/linux/mmqgis/

42. Getis A, Ord JK. Local spatial statistics: an overview. In: Longley P, Batty M, editors, Spatial analysis: modelling in a GIS environment. Cambridge: Geoinformation International; 1996. p 261-77.

43. Bivand R, Altman M, Anselin L, Assunção R, Berke O. Package 'spdep' Spatial Dependence: Weighting Schemes, Statistics and Models. Repository CRAN. 2016.

44. $\mathrm{R}$ Development Core Team, version 3.2.2. R: A language and environment for statistical computing. Vienna. R Foundation for Statistical Computing, 2015.

45. Lotwick HW, Silverman BW. Methods for analyzing spatial processes of several types of points. J R Stat Soc. 1982;44(3):406-13.

46. Teixeira-Neto RG, Silva ES, Nascimento RA, Belo VS, Oliveira CDL, Pinheiro LC, Gontijo CMF. Canine visceral leishmaniasis in an urban setting of Southeastern Brazil: an ecological study involving spatial analysis. Parasit Vectors. 2014;7(1):485.

47. Bivand R, Rowlingson B, Diggle P, Petris G, Eglen S. Package 'splancs'. R package version 2.01-40. 2017 [updated 2020, cited 2020]. Available from: https://cran.r-project.org/web/packages/splancs/splancs.pdf

48. Superintendência de Controle de Endemias (SUCEN). Secretaria de Estado da Saúde. Boletim do Sistema de Vigilância Epidemiológico do ano de 1979-1980, do serviço Regional 11 - Marilia. Programa de Controle da Esquistossomose Mansônica no estado de São Paulo. São Paulo: SUCEN; 1980.

49. Superintendência de Controle de Endemias (SUCEN). Secretaria de Estado da Saúde. Boletim do Sistema de Vigilância Epidemiológico do ano de 2009-2012, do serviço Regional 11 - Marilia. Programa de Controle da Esquistossomose Mansônica no Estado de São Paulo. São Paulo: SUCEN; 2012.

50. Paraense WL, Corrêa LR. Unsusceptibility of Biomphalaria occidentalis to infection with a strain of Schistosoma mansoni. Mem Inst Oswaldo Cruz. 1982;77(1),55-8.

51. Figueiredo WSA. Epidemiologia da esquistossomose mansônica e o processo de organização espacial: o caso do município de Ourinhos, S.P. Faculdade de Saúde Pública. Departamento de Epidemiologia. 2000;40-52,127-37.

52. Coura-Filho P. Schistosomiasis mansoni in urban territory. 2. A theoretical approach to the accumulation, concentration, and centralization of capital and the production of disease. Cad Saude Publica. 1997;13(3):415-24.

53. Paraense WL. The Schistosome vectors in the Americas. Mem Inst Oswaldo Cruz. 2001;96(suppl.):7-16.

54. Teles HMS, Vaz JF. Distribuição de Biomphalaria glabrata (Say, 1818) (Pulmonata, Planorbidae) no Estado de São Paulo, Brasil. Rev Saude Publica. 1987;21(6):508-12.

55. Pieri OS. Perspectivas no controle ambiental dos moluscos vetores da esquistossomose. Tópicos em Malacologia Médica. 1995;239-52.

56. Teles HMS. Ecological aspects of Biomphalaria Preston, 1910 in the State of Sao Paulo, Brazil. I Syntopia Cienc Cult. 1988;40(4):374-79.

57. Figueiredo CC. Dispersion of Biomphalaria straminea in the State of Sergipe, Brazil. Mem Inst Oswaldo Cruz. 1989;84(3):383-87.

58. Piza JDT, Ramos ADS. Os focos autóctones de esquistossomose no Estado de São Paulo. Arq Hig. 1960;25(86):261-71.

59. Teles HMS. Distribuição de Biomphalaria straminea ao Sul da Região Neotropical, Brasil. Rev Saude Publica. 1996;30(4):341-49. 
60. Fernandez MA, Thiengo SC, Xavier IG, Batista EJ, Tuan R. Susceptibility of Biomphalaria glabrata from a rural area in the medium Paranapanema River, São Paulo, Brasil, to infection with Schistosoma mansoni. XXV Congresso Brasileiro de Parasitologia; 2017, Búzios, Rio de Janeiro; 2017, 659. [updated 2021; cited 2021]. Available from: http:// antigo.parasitologia.org.br/cbp17/cbp17_content/CBP17_paper_659.pdf
61. Nascimento GL, Pegado HM, Domingues ALC, Ximenes RADA, Itria A, Cruz LN, Oliveira MRFD. The cost of a disease targeted for elimination in Brazil: the case of schistosomiasis mansoni. Mem Inst Oswaldo Cruz. 2019;114. 